\title{
Systematic Literature Review on Female Entrepreneurship: Citation and Thematic Analysis
}

Surangi H.A.K.N.S.

Department of Commerce and Financial Management, Faculty of Commerce and Management Studies, University of Kelaniya, Sri Lanka

surangins@kln.ac.lk

\begin{abstract}
This paper carries out a systematic review of the literature on female entrepreneurship. A total of 192 articles focusing on female entrepreneurship, published between 2000 and 2019 have been analysed. The purpose of this paper is to give a current knowledge of the sub-areas in female entrepreneurship research by focusing on two aspects. First, it reviews research papers by using citation analysis to identify and categorize the main areas of female entrepreneurship presently interesting the attention of the research community. Second, a thematic analysis is done to explore the precise themes being researched. Regardless of many of publications and their variety, the present study reveals six different themes. Defining female entrepreneurship is problematic, entrepreneurship is gender specific, from hard issues to soft issues, family is the main responsibility, female entrepreneurs are underperformers and networking is unique for women were found as main themes. A number of research gaps are found out, in order to persuade new avenues and angles in the female entrepreneurship field of research that may be fruitful in filling these gaps.
\end{abstract}

Keywords: Female entrepreneurship, systematic literature review, citation analysis, thematic analysis

Copyright: (C) 2020 Surangi H.A.K.N.S. This is an open access article distributed under the Creative Commons Attribution License, which permits unrestricted use, distribution, and reproduction in any medium, provided the original work is properly cited.

Correspondence: surangins@kln.ac.lk

ORCID of authors: Surangi H.A.K.N.S. -(D)https://orcid.org/0000-0002-2671-2212

DOI: http://doi.org/10.4038/kjm.v9i2.7643 


\section{Introduction}

While female entrepreneurship is considered as the main area of economic and social development in most countries, academic research into their entrepreneurial activities is relatively limited (Roomi 2009, Ahl 2002). Brush and Cooper (2012) revealed that while many women are participating for entrepreneurial activities, research of female entrepreneurs account for less than $10 \%$ of the entrepreneurship literature. The majority of researchers tend to address the entrepreneurial profile, psychological traits, push and pull factors, educational background and experiences, constraints faced by them, leadership style and start-up activities (Henry, Foss and Ahl 2013, Brush 1992, Brush and Cooper 2012, Welter 2004). In recent years, there has been a move in the research agenda to an increasing focus on soft issues rather than hard issues, including work/family balance and nonfinancial resources such as personal networks (Brush and Cooper 2012).

Moreover, with the increasing of the publication towards female entrepreneurship, new identities of women and mismatches have developed. The area of female entrepreneurship research absences systematic categorization, with a tendency to start new avenue with every study (Henry, Foss and Ahl 2013). There is, therefore, a possibility of the field not moving forward and lacking strength (Henry, Foss and Ahl 2013). Therefore, there is a wide scope in the area and it is needed to arrange for systematic categorization to contribute towards further development in the female entrepreneurship area. Above all, this will support to identify the major arguments, debates and themes in the literature, and the existing research gaps and new related avenue of research.

Therefore, the purpose of this research is to understand the current knowledge and give a clearer picture of female entrepreneurship research area. First, the author reviews current debate, argument and contributions in the field, and identify the significant and specialization areas of within it. Second, the present study works to recognize a number of emerging themes in female entrepreneurship area, in order to identify gaps and new avenues in the particular field. In this setting, citation and thematic analysis are used to identify most influential papers and prominent researchers that help to identify the main categories of research in the field.

\section{Literature Review - Female Entrepreneurship}

The women participation of the entrepreneurial activities has been increased significantly, and is now notable in both developed and developing countries (UN 2007). Regardless of the growth in the number of female-owned businesses, the female entrepreneurship rate is lower than their male counterparts in many counties (UNDP 2011). According to GEM (2014), only two countries have more women than men involved in entrepreneurship activities: Ghana and Thailand. In many developing countries women participate out of necessity, because they need to generate an income for their families and they have few other job opportunities (GEM 2011).

The growth of female entrepreneurship statistics has attracted academic community, and the field has itself developed as a separate research field after 1980 (Tulus 2009). Academic interest in female entrepreneurship is stimulated by both the economic and social developments and implications of this phenomenon. As entrepreneurship is identified as a major source of employment, income generation, poverty alleviation, regional development and innovation, women are an important and available resource that countries may use 
to achieve economic progress (UNDP 2011). Historically, most Asian societies have been patriarchal, with the woman considered as a secondary person'. Gender equality is vital to economic and human development in a country. Removing gender inequalities gives societies a better chance to develop (Shaw 2006). Therefore, encouraging women to become involved in entrepreneurial activities may lead to economic prosperity and improve their standards of living (Ranasingha 2009).

As the female participation of the entrepreneurial activities started to increase quickly (Bygrave 2006), researches argued that female entrepreneurship should be considered as a separate research field. Research revealed that female entrepreneurs are less success in terms of profit, sales, number of employees, asset value and survival periods compared to their male counterparts (Carter and Marlow 2007. As is evident in a review of research articles published between 1982 and 2000 on female entrepreneurship (Ahl 2002) (Henry, Foss and Ahl 2015), many researchers labelled female entrepreneurs as underperformers and subordinators. Currently, it can be observed that researchers mainly focus on softer issues, such as competing family and business, social capital (Brush and Cooper 2012), sustainable entrepreneurship, (Jennings and Brush 2013), as well as decisionmaking styles such as effectuation, and family-embeddedness perspective of entrepreneurship including mumprenurs and entrepreneurial couples (Bruin, Brush and Welter 2007).

Research towards gender and entrepreneurship point out the limitations in comparing and relating the experiences of entrepreneurial men and women. Consequently, scholars recommend that researchers try to find a more granular understanding, one that considers gender issues as they relate to culture where they live due to its changing nature. Yet, while there has been a number of discussions on female participation for entrepreneurial activities, there has been a lack of studies towards female entrepreneurship, and their involvement.

\section{Methodology}

Research in female entrepreneurship has considerably expanded in the last two decades; considering it as a separate research field. In order to identify the most recent contribution on female entrepreneurship and identify main areas of categorization, the author has used a systematic method to find articles. This method is based on the recommendations from previous researchers to confirm it is systematic, transparent and thus replicable (Bruin, Brush and Welter 2007). Only journal articles have been considered in this research since they are considered as reliable sources. Books, magazines, thesis, book chapters and conference papers have been excluded due to the differences of the review process.

Creating search strategies for systematic literature reviews, is challenging task. Researcher conducted a general Boolean search across the broad entrepreneurship literature and initial Boolean search produced hundreds rather than thousands of hits. Different interfaces need different sentence structure, the distinct set of rules and symbols unique to each database that explain how a correctly constructed search operates. Common syntax workings comprise the use of parentheses and Boolean operators such as "AND," "OR," and "NOT," which are offered in all major interfaces. Generate single-line queries in a text document, which permits immediate checking of the relevance of obtained references and efficient optimization. At first, the Scopus database was used for findings journal articles published from 2000 to 2019 including the keywords female 
entrepreneurship, women entrepreneurship and gender and entrepreneurship. Choosing this database is due to its recognition and extensive coverage of different research disciplines. Initial search in Scoopers produced 154 papers. Moreover, the same procedure (search) was performed in other more recognized databases such as Social Science Citation Index, ABI, ProQuest, and Science Direct. After examining all the papers, duplicate documents were eliminated, and a total of 252 papers were identified. The author read all the abstracts to ensure that the paper really focuses on female entrepreneurship. When there was a doubt, the author read the whole paper to get confirmation whether article is related or not to the particular area. This process revealed 60 articles not concentrating on female entrepreneurship area, and these were therefore removed. Finally, the analysis takes in the remaining 192 papers.

A citation analysis was performed to identify key researchers in the area and the most influential papers within the specific time period (Henry, Foss and Ahl 2013, Brush 1992; Brush and Cooper 2012, Welter 2004). A most cited publication can be considered as providing important scientific knowledge that is used as a foundation for further development of particular research area. Therefore, following the approach adopted by Brush and Cooper (2012), the researcher found the most-cited publications within the data set of 192 papers. The classifications of different research areas which emerged from the most-cited research papers were used as a foundation for the thematic analysis. Thus, themes and sub-themes shows the major arguments, debates and conceptual linking with research questions

\section{Data Analysis and Discussion}

Data analysis was done in two ways. First, citation analysis was conducted to identify most influential papers and categorize the sub areas of female entrepreneurship, which currently appealing the attention of the researchers. Secondly, a thematic analysis was conducted to go dig deeper in the particular area and identify the specific themes being researched.

\section{Citation Analysis}

A total of 31 influential papers were identified through citation analysis based on the highest number of citations. The author carefully reads all 31 papers to identify the main debate and arguments areas being addressed. This bring about in the identification of six categories of papers, and they are labelled below. Table 01 shows the arrangement of these 31 highly-influential papers into the different content clusters.

\section{Thematic Analysis- Themes Derived from the Literature}

All papers were classified into the different groups and themes within each group were compared

Within each category, several sub-themes were identified (see figure 01), and the thematic analysis are now interpreted and described.

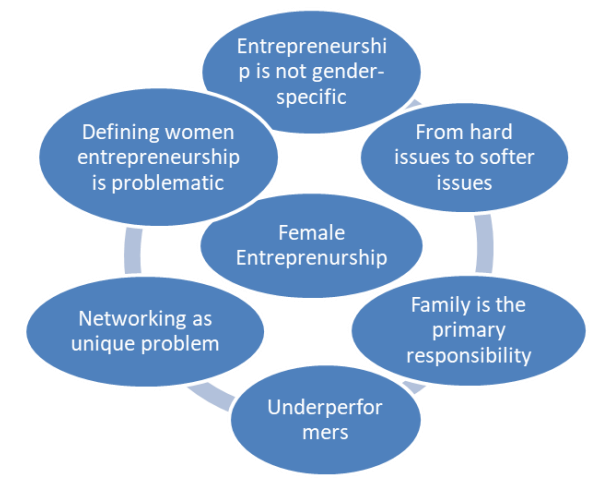

\section{Figure 01: Themes Derived from Literature Review on Female Entrepreneurship}


Table 01: Most Influential Papers (2000-2019)

\begin{tabular}{|c|c|c|c|}
\hline Category & Author & Journal & Cites \\
\hline \multirow{5}{*}{$\begin{array}{l}\text { individual 's traits, } \\
\text {,startup motives, } \\
\text { experience, } \\
\text { constraint }\end{array}$} & Ahl, H. (2006) & $\begin{array}{l}\text { Entrepreneurship Theory and } \\
\text { Practice }\end{array}$ & 134 \\
\hline & $\begin{array}{l}\text { Ahl, H. and Nelson, } \\
\text { T.(2012) }\end{array}$ & $\begin{array}{l}\text { International Journal of Gender } \\
\text { and Entrepreneurship }\end{array}$ & 120 \\
\hline & $\begin{array}{l}\text { Bruin, A.D., Brush, } \\
\text { C.G. and Welter, F. } \\
(2007)\end{array}$ & $\begin{array}{l}\text { Entrepreneurship Theory and } \\
\text { Practice, }\end{array}$ & 94 \\
\hline & Fiona, W. (2009) & $\begin{array}{l}\text { Journal of Developmental } \\
\text { Entrepreneurship }\end{array}$ & 67 \\
\hline & $\begin{array}{l}\text { Jennings, J.E. and } \\
\text { Brush, C.G. (2013 }\end{array}$ & $\begin{array}{l}\text { The Academy of Management } \\
\text { Annals }\end{array}$ & 83 \\
\hline \multirow[t]{5}{*}{$\begin{array}{l}\text { Constrains faced } \\
\text { by female } \\
\text { entrepreneurs }\end{array}$} & $\begin{array}{l}\text { Bruni, A., Gherardi, } \\
\text { S. and Poggio, B. } \\
\text { (2004) }\end{array}$ & $\begin{array}{l}\text { Gender, Work and } \\
\text { Organization }\end{array}$ & 88 \\
\hline & $\begin{array}{l}\text { Garcia, M.C.D. and } \\
\text { Carter, S. (2009) }\end{array}$ & $\begin{array}{l}\text { International Journal of Gender } \\
\text { and Entrepreneurship }\end{array}$ & 79 \\
\hline & $\begin{array}{l}\text { García, M.C.D. and } \\
\text { Welter, F. (2019) }\end{array}$ & $\begin{array}{l}\text { International Small Business } \\
\text { Journal }\end{array}$ & 112 \\
\hline & $\begin{array}{l}\text { John W. and Rick } \\
\text { N. (2009) }\end{array}$ & $\begin{array}{l}\text { International Journal of Gender } \\
\text { and Entrepreneurship }\end{array}$ & 56 \\
\hline & $\begin{array}{l}\text { International Journal } \\
\text { of Gender and } \\
\text { Entrepreneurship }\end{array}$ & $\begin{array}{l}\text { International Journal of } \\
\text { Tourism Research }\end{array}$ & 37 \\
\hline \multirow[t]{5}{*}{$\begin{array}{l}\text { Work and family } \\
\text { balance }\end{array}$} & $\begin{array}{l}\text { Bruni, A. and } \\
\text { Perrotta, M. (2014) }\end{array}$ & $\begin{array}{l}\text { International Journal of } \\
\text { Entrepreneurial Behaviour and } \\
\text { Research }\end{array}$ & 61 \\
\hline & $\begin{array}{l}\text { Duberley, J. and } \\
\text { Carrigan, M. (2012) }\end{array}$ & $\begin{array}{l}\text { International Small Business } \\
\text { Journal }\end{array}$ & 97 \\
\hline & $\begin{array}{l}\text { Ekinsmyth, C. } \\
(2013)\end{array}$ & $\begin{array}{l}\text { Journal of Entrepreneurial } \\
\text { Behaviour \& Research }\end{array}$ & 145 \\
\hline & $\begin{array}{l}\text { Elvin-Nowak, Y. } \\
\text { and Thomsson, H. } \\
(2001)\end{array}$ & Gender and Society & 29 \\
\hline & Kirkwood, J. (2009) & $\begin{array}{l}\text { Women in Management } \\
\text { Review }\end{array}$ & 79 \\
\hline \multirow[t]{2}{*}{$\begin{array}{l}\text { Female } \\
\text { entrepreneurs are } \\
\text { less success, } \\
\text { underperforms }\end{array}$} & $\begin{array}{l}\text { Carter, S., Mwaura, } \\
\text { S., Ram, R., Trehan, } \\
\text { K. and Jones, T. } \\
(2015)\end{array}$ & $\begin{array}{l}\text { International Small Business } \\
\text { Journal }\end{array}$ & 138 \\
\hline & $\begin{array}{l}\text { Jayawarna, D., } \\
\text { Jones, O. and } \\
\text { Marlow, S. (2015) }\end{array}$ & $\begin{array}{l}\text { Scandinavian Journal of } \\
\text { Management }\end{array}$ & 34 \\
\hline
\end{tabular}




\begin{tabular}{|c|c|c|c|}
\hline & Kirkwood, J. (2012) & $\begin{array}{l}\text { Journal of Small Business and } \\
\text { Entrepreneurship }\end{array}$ & 91 \\
\hline & $\begin{array}{l}\text { Marlow, S., Henry, } \\
\text { C. and Cater, S. } \\
\text { (2009) }\end{array}$ & $\begin{array}{l}\text { International Small Business } \\
\text { Journal }\end{array}$ & 187 \\
\hline & $\begin{array}{l}\text { Marlow, S. and } \\
\text { McAdam, M. (2013) }\end{array}$ & $\begin{array}{l}\text { International Journal of } \\
\text { Entrepreneurial Behaviour \& } \\
\text { Research }\end{array}$ & 121 \\
\hline \multirow{6}{*}{$\begin{array}{l}\text { Non-financial } \\
\text { resources such as } \\
\text { personal networks }\end{array}$} & $\begin{array}{l}\text { Ahl, H., Marlow, S. } \\
\text { (2012) }\end{array}$ & Gender, work and Organization & 154 \\
\hline & $\begin{array}{l}\text { Brush and Cooper } \\
\text { (2012) }\end{array}$ & $\begin{array}{l}\text { Entrepreneurship and Regional } \\
\text { Development }\end{array}$ & 165 \\
\hline & $\begin{array}{l}\text { Chris, D., Nerys, } \\
\text { F.L., Eillen, S. and } \\
\text { Bill, O.G. (2011) }\end{array}$ & $\begin{array}{l}\text { The International Journal of } \\
\text { Entrepreneurship and } \\
\text { innovation }\end{array}$ & 35 \\
\hline & $\begin{array}{l}\text { D`Exelle, B. and } \\
\text { Holvoet, N. (2011) }\end{array}$ & Feminist Economics & 47 \\
\hline & Durbin, S. (2011) & $\begin{array}{l}\text { Gender, Work and } \\
\text { Organization }\end{array}$ & 91 \\
\hline & Foss, L. (2010) & $\begin{array}{l}\text { International Journal of Gender } \\
\text { and Entrepreneurship }\end{array}$ & 94 \\
\hline \multirow{5}{*}{$\begin{array}{l}\text { Female } \\
\text { entrepreneurs as } \\
\text { subordinates }\end{array}$} & Coleman, S. (2007) & $\begin{array}{l}\text { Journal of Business and } \\
\text { Entrepreneurship }\end{array}$ & 71 \\
\hline & $\begin{array}{l}\text { Cudmore, B.A., } \\
\text { Troshani, A. and } \\
\text { McCoy, J. (2009) }\end{array}$ & The Entrepreneurial Executive & 24 \\
\hline & $\begin{array}{l}\text { Marlow, S. and } \\
\text { Patton, D. (2005) }\end{array}$ & $\begin{array}{l}\text { Entrepreneurship Theory and } \\
\text { Practice }\end{array}$ & 91 \\
\hline & $\begin{array}{l}\text { Marlow, S. and } \\
\text { Swail, J. (2014) }\end{array}$ & $\begin{array}{l}\text { Entrepreneurship and Regional } \\
\text { Development }\end{array}$ & 77 \\
\hline & Welter, F. (2004) & $\begin{array}{l}\text { Journal of Small Business and } \\
\text { Enterprise Development }\end{array}$ & 115 \\
\hline
\end{tabular}

\section{Defining Women Entrepreneurship is} Problematic

In the last three decades, entrepreneurship has received much attention from all domains of society such as researchers, policy makers, social workers, politicians and supporting institutions (Roomi 2009). Developed nations see innovation as the main characteristic of entrepreneurship, whereas developing countries consider entrepreneurship as a just selfemployment (Roomi 2009). Both these ideas lead to desired social and economic development in any countries which promote entrepreneurship through policies and support mechanism (Roomi 2009).

Like their male counterparts, there is no standard definition of what constitutes a female entrepreneur (Moore 1990), except for the fact that she is a woman. The initial research on female entrepreneurs concentrated on their characteristics (Brush 1992). Demographics, psychological traits and business skills are all characteristics that are used to define a female entrepreneur (Brush 1992). However, these characteristics are all 
based on the research conducted on male entrepreneurs (Bird and Brush 2002, Hytti 2005). To confuse matters even further, researchers define that entrepreneur is the person who bring new, unique ideas to the market (Deakins, D, O'Neill, and Mileham 2006). In this setting, defining female entrepreneurship is more problematic. Since most of the businesses run by women, in general, are in traditional sectors such as craft, garment, retail, hospitality and other low-end services. Therefore, these women cannot be considered as entrepreneurs and then fall in to the category of business owners (Marlow and Patton 2005, Roomi 2009). The tourism sector is characterized by, seasonal demand, low skills labour, lack of creativity and low levels of innovation (Bosworth and Farrell 2011). However, Carter et al. (2003) define female entrepreneurship as a broad term to describe female self-employment and business ownership.

\section{Entrepreneurship is Not Gender-Specific}

In entrepreneurship literature, it was considered that entrepreneurial behaviour was not gender-specific and entrepreneurs as a one group, regardless of gender (Brush 2006). After 1980s, researchers began to consider female entrepreneurs as a separate research area more than just a small division of entrepreneurship (Moore and Buttner 1997).

Therefore, it is not appropriate to conclude that the findings of male entrepreneurs applied similarly to women (Loscocco et al. 2009). In response to this debate, female entrepreneurship area was emerged as separate field. Then, female entrepreneurship studies started to propose images of women matching masculine characteristics rather than feminist and having similar interest as their male counterparts (Brush 2006). The entrepreneurship is considered as male dominant discipline and many entrepreneurs' stories were evident in how images of an iron lady were used to label female entrepreneurs, whereas traits related with femininity, such as caring, love and emotion were rarely studied as being accompanying with entrepreneurship (Bruni, Poggio and Gherardi 2005).

\section{From Hard Issues to Softer Issues}

As is evident in a female entrepreneurship literature, the majority of researchers tend to address the entrepreneurial traits, reason for choosing entrepreneurship as a career option, demographic factors, the problems faced by women, leadership style and start-up difficulties. Recent years have witnessed a shift in the research agenda from this early focus to an increasing emphasis on softer issues, including multiple identities of women such as entrepreneur, mother, wife and non-financial resources such as social capital (Brush and Cooper 2012), sustainable entrepreneurship and entrepreneurial couple (Jennings and Brush 2013), as well as decision-making styles such as effectuation, and familyembeddedness perspective of entrepreneurship (Bruin, Brush and Welter 2007).

\section{Primary Responsibility is the Family}

One of the tendencies in female entrepreneurship area is to study on societal expectations of women towards family responsibilities affects those women business success, (Ahl 2006). Therefore, many researchers focus on the assumption that female entrepreneurs' priority is the family over business (Bruni, Poggio \& Gherardi 2005), the importance of gender roles and division of labour based on gender within conceptualizations of entrepreneurship becomes apparent. Certainly, society sees woman as producers and reproducers, leading women to deal with the task of balancing family commitment with business matters (Woldie and Adersua 2004). An understanding of the multiple identities of 
women as business owners and mothers or housewives is evident in how the balancing act of two different entities is one of the most pressing issues in front of every society (Crompton et al. 2007). Competing family and business is especially difficult for women who engage in tourism related business, as unique challenges exist due to intensity, seasonality and long hours. The influence of the intensity of tourism on female business was observed in Kousis's (1989) study of a particular tourism community, where female entrepreneurs work 12-24 hour days and have no free weekends or holidays during the 6 month tourist high season. Engaging in tourism also has other uniqueness, as Ateljevic and Doorne's (2003) research on tourism entrepreneurs in Croatia indicates, where dealing with tourists seems to involve an association with femininity, and accordingly, men reject choosing tourism related business, as it is below their male self-respect. All these observations on how social norms and society expectation relate with entrepreneurship propose the need for a more critical analysis of what female entrepreneurship actually is.

\section{Female Entrepreneurs are Underperformers}

Female entrepreneurs exhibit constrained performance, but this is not synonymous with under-performance, a label which is a myth (Marlow and McAdam 2013). However, it is still common for many entrepreneurship studies to portray female entrepreneurs as less success compared to their male counterparts (Marlow and McAdam 2013), the reason for which is often connected with how women purposefully limit their business growth and activities in order to prioritize family responsibilities (Butler 2003). This is contrasted with how entrepreneurship is rooted in neoclassical economic theories that are based on labelling entrepreneurship as economic activity, rather than social activity such as prioritizing family responsibilities (Walby 2000). To this level new scholors in the field of female entrepreneurship is not only based on economic perspective that, in order to develop entrepreneurial theory, dominant economic theories need to be reevaluated to show how gender contribute to define and understand entrepreneurship (Ahl 2006, Ahl and Marlow 2012, Ahl and Nelson 2010, Hughes and Jennings 2012).

Marlow and Carter (2004) strongly relate the underperformance of femaleentrepreneurs to their early undercapitalization. They argue that this initial undercapitalization is not limited to financial capital, but also includes social and human capital, which consist of previous experience, as well as access to suitable professional and personal networks.

Networking as a Unique Issue for Female Entrepreneurs

Researchers revealed that women participation for entrepreneurial activities is low due to lack of resources including social networks and social capital (Klyver, Hindle \& Meyer 2008). Networking is particularly important for small businesses compared to large organizations as they have limited resources and lack contacts with external actors, and they can't achieve their objectives by themselves without support from networks ( $\mathrm{Ng}$ and Keasey 2010). Moreover, some researchers reveal that women have been identified to be more dependent on other parties, and have more concern for, others, while men have been identified as more independent (Sonfield and Lussier 2009).

Men and women form and develop different types of social networks, and researchers suggested that network differences lead to different level of business development (Sonfield and Lussier 2009). The literature found that women tend to include more informal networks and they have more family 
members and close friends in their networking composition (Greve and Salaff 2003, Moore 1990, Klyver 2011, Watson 2011).

Women 's networks identified as a considerable amount of less wealthy, less powerful and less respected actors (D`Exelle and Holvoet 2011). Moreover, literature revealed that women's formal networks are limited and tend to be more similar with regard to capital experience, education, marital and work status than men's formal networks (D‘Exelle and Holvoet 2011, Batjargal et al. 2009) Some studies propose that both men and women prefer to form and develop relationships with people of their own sex (Garcia and Carter 2009, Belliveau 2005); contrastingly, others reveal that the networks of both men and women tend to contain mostly of men (Aldrich et al. 1989, Shaw 2006). The importance of making contacts for a female entrepreneur might be significant at the start-up level of the business (Garcia and Carter 2009), providing necessary resources (Roomi 2009) and bringing solutions to the specific problems that challenge women, such as business-family conflict or lack of acceptability (Roomi 2009). It has been shown that men and women live in different positions in social structures, with men holding positions of higher status and fewer domestic responsibilities (D`Exelle and Holvoet 2011, Batjargal et al. 2009). According to the literature, women may be expected to contact men for business opportunities, tangible and in-tangible resources, because men are supposed as having higher status and are in a better position to access to resources (Roomi 2009, Klyver and Grant 2010).

Moreover, other authors argue that a large support network can create conflicting demands on the socio-emotional attention of female business owners (Batjargal et al. 2009). In this context, female entrepreneurs are likely to struggle to meet the expectations of both those who compliment them for being successful and those who encourage them to be responsible mothers, spouses and daughters simultaneously. This can result in an inconsistency in women's commitment to a venture, thereby negatively affecting their venture's growth.

Therefore, some authors conclude that a large network may constitute a disadvantage for female entrepreneurs. Moreover, female entrepreneurs normally raise seed capital from relatives and friends (Batjargal et al. 2009), yet the informal nature of these contacts create various claims from network members on the business performance which in turn reduces the capital available for the business (Granovetter 1983).

Relating to men and women network size, frequency and density some scholars have indicated that the size of networks varies slight, but that differences happen within groups of men and women (Santos 2009, D‘Exelle and Holvoet 2011, Greve and Salaff 2003). Interestingly, some studies show that intra-group differences may often be correlated with life-cycle, which are highly gendered (D`Exelle and Holvoet 2011). For example, Moore (1990) revealed that, for women, network size, frequency and density are low at childbearing age, when the burden of family responsibilities is particularly heavy. Greve and Salaff (2003) similarly suggest that young children limit the networks of their parents, particularly their mothers. Moreover, Moore (1990) showed that, at later ages, women's networks again increase, whereas those of men weakening.

\section{Conclusion}

The main purpose of this paper has been to review the theoretical and empirical literature related to female entrepreneurship. According to this study, in a worldwide marketplace, female 
entrepreneurs are a vibrant and growing economic force. As the female population is growing in most countries, entrepreneurial women are still a small amount of the total population. However, higher participation of women in the entrepreneurial activities is a prerequisite for social and economic development of any country. This paper also revealed that women 's contribution to business is certainly undervalued, as majority works in the informal sector, and their business activity is not replicated in national statistics, particularly in developing countries. So, female entrepreneurship can be understood as invisible entrepreneurship.

This study also found that female entrepreneurship statistics is low in business, making female entrepreneurship an important, untapped economic potential. In general, female businesses differ from those of men, being smaller, high failure rate and less success, and typically limited to certain low-value sectors such as tourism, retail and service industries. The paper has further reviewed main issues relating to gender differences discussed in the literature on female entrepreneurship. Women face various gender-specific problems when starting their own ventures. These include limited access to finance, lack of network composition, societal expectations, gender-stereotypes, multiple identities and cultural barriers. Many researchers showed a fitting together between masculinity and entrepreneurship, leading to the assumption that female entrepreneurs must follow masculine ethics, as feminine ideals of caring and love are regarded as weaknesses in entrepreneurship theorizing (Brush 2006). More recent studies which focus on female entrepreneurship from a feminist approach highlight how different conceptualizations of entrepreneurship are worthwhile, such as a recent study challenging women's underperformance myth (Marlow and McAdam 2013).
To recap the overall review, several observations of research gaps (Table 2) are identified from previous empirical studies.

The quantity of knowledge that these studies contribute is appreciable, and each has added new dimensions to the existing literature. Current knowledge of female entrepreneurship indicates a growth that outpaces other businesses, but research in this area remains limited (Brush and Cooper 2012, Warren 2004). Brush and Cooper (2012) highlight that while women are contributing to the economy significantly, studies towards female entrepreneurship represent for less than $10 \%$ of the academic literature on entrepreneurship. The studies of female business owners that exist in reputed journals in the area tend to discourse the different constraints including issues related to balancing a business and childcare and trait differences in male and individuals that challenge traditional gender roles, and women's subordinate role is consistently highlighted. Furthermore, female entrepreneurs show constrained performance but this is not synonymous with under-performance, and the underperformance label is a myth (Marlow and McAdam 2013). However, it can be widely seen female entrepreneurs as underperformers in many entrepreneurship research (Marlow and McAdam 2013), the reason for which being frequently prioritized with family responsibilities.

This study contributes to the female entrepreneurship research area by classifying and characterizing of the vast amount of publications over the period 2000-2019 and showing gaps within each of these classifications. This situation signals out that still there is a wide scope for the female entrepreneurship research area. With regard to limitations, this research does not allow for first-hand or authentic experiences as findings mainly based on previous literature. 
Table 02: Gaps in the Female Entrepreneurship Literature

\begin{tabular}{|c|c|c|}
\hline Research Area & Previous Studies & $\begin{array}{l}\text { Little or no research } \\
\text { (Research gaps) }\end{array}$ \\
\hline \multirow[t]{10}{*}{$\begin{array}{l}\text { Female } \\
\text { Entrepreneurship }\end{array}$} & $\begin{array}{l}\text { This area is mainly explored by } \\
\text { researchers in developed countries. } \\
\text { Main } 3 \text { regions are the The UK, the }\end{array}$ & $\begin{array}{l}\text { Other contexts, particularly } \\
\text { developing countries }\end{array}$ \\
\hline & USA and Australia & $\begin{array}{l}\text { New research topics : } \\
\text { opportunity identification, }\end{array}$ \\
\hline & $\begin{array}{l}\text { Research topics: individual traits, } \\
\text { start-up motives, demographic } \\
\text { characteristics, constraints and } \\
\text { leadership style }\end{array}$ & $\begin{array}{l}\text { entrepreneurial emotion, } \\
\text { social entrepreneurship, } \\
\text { social capital, incubation, } \\
\text { decision-making styles such } \\
\text { as bricolage or effectuation, }\end{array}$ \\
\hline & Descriptive exploration & $\begin{array}{l}\text { the copreneur, family } \\
\text { embeddedness }\end{array}$ \\
\hline & Gender as variable & \\
\hline & Quantitative studies are dominant & $\begin{array}{l}\text { Theoretical focus } \\
\text { (researchers }\end{array}$ \\
\hline & $\begin{array}{l}\text { Sectors: retail, servicers, agriculture, } \\
\text { lack of sector focus }\end{array}$ & $\begin{array}{l}\text { stared to use conceptual } \\
\text { frameworks) Gender as } \\
\text { influence }\end{array}$ \\
\hline & $\begin{array}{l}\text { Findings: subordinate roles, } \\
\text { underperformance }\end{array}$ & $\begin{array}{l}\text { Less feminist critique, in- } \\
\text { depth qualitative } \\
\text { methodologies such as life } \\
\text { histories, case studies or } \\
\text { discourse analysis }\end{array}$ \\
\hline & & $\begin{array}{l}\text { Manufacturing, } \\
\text { construction, industry- } \\
\text { specific }\end{array}$ \\
\hline & & $\begin{array}{l}\text { New findings: female are } \\
\text { not underperformers, } \\
\text { female-owned businesses } \\
\text { showed constrained } \\
\text { performance but this does } \\
\text { not equate to under- } \\
\text { performance }\end{array}$ \\
\hline
\end{tabular}

\section{References}

Ahl, H. (2006). Why research on women entrepreneurs needs new directions. Entrepreneurship Theory and Practice, 30 , $595-$ 621.https://doi.org/10.1111/j.15406520.2006.00138.x
Ahl, H., \& Marlow, S. (2012). Exploring the dynamics of gender, feminism and entrepreneurship: advancing debate to escape a dead end? Organization, 19(5), 543-562.

https://doi.org/10.1177/13505084124486 95 
Ahl, H., \& Nelson, T. (2010). Moving forward: institutional perspectives on gender and entrepreneurship. International Journal of Gender and Entrepreneurship, 2(1), 5 - 9 . https://doi.org/10.1108/17566261011044 259

Batjargal, B., Hitt, M., Webb, J., Arregle, J. L., \& Miller, T. (2009). Women and men entrepreneurs' social networks and new venture performance across cultures. Academy of Management Proceedings, $1(1)$, $1-6$. 10.5465/AMBPP.2009.44247734

Bird, B., \& Brush, C. (2002). A gendered perspective on organizational creation. Entrepreneurship Theory and Practice, 26(3), 41-65. https://doi.org/10.1177/10422587020260 0303

Bosmaa, N., Hesselsb, J., Schutjensa, V., \& Praag, M. V. (2012). Entrepreneurship and rolemodels. Journal of Economic Psychology, 33(2), 34-45. DOI: 10.1016/j.joep.2011.03.004

Bosworth, G. (2012). Characterising rural businesses-tales from the paperman. Journal of Rural Studies, 28, 499-506. DOI: 10.1016/j.jrurstud.2012.07.002

Bosworth, G., \& Farrell, H. (2011). Tourism Entrepreneurs in Northumberland. Annals of Tourism Research, 38(4), 14741494.https://doi.org/10.1016/j.annals.201 1.03 .015

Bourne, K. A. (2010). The paradox of gender equality: an entrepreneurial case study from Sweden. International Journal of Gender and Entrepreneurship, 2(1), 1026.

Bruin, A. D., Brush, C. G., \& Welter, F. (2007). Advancing a Framework for
Coherent Research on Women's Entrepreneurship. Entrepreneurship Theory and Practice, 1042-2587.

Bruni, A., \& Perrotta, M. (2014). Entrepreneuring together: his and her stories. International Journal of Entrepreneurial Behaviour and Research, 20(2), 108-127. DOI: 10.1108/IJEBR-122011-0187

Bruni, A., Gherardi, S., \& Poggio, B. (2004). Doing gender, doing entrepreneurship:An ethnographic account of intertwined practices. Gender, Work and Organization, 11(4), 406-429. DOI: 10.1111/j.1468-0432.2004.00240.x

Brush, C. G., \& Cooper, S. Y. (2012). Female entrepreneurship and economic development: An international perspective. Entrepreneurship and Regional Development, 24(1), 1-6. https://doi.org/10.1080/08985626.2012.6 37340

Carter, N., Brush, C. B., Greene, P. G., Gatewood, E., \& Hart, M. (2003). Women entrepreneurs who break through to equity financing: the influence of human, social and financial capital. Venture Capital, $5(1)$,

28.https://doi.org/10.1080/136910603200 0082586

Carter, S., Mwaura, S., Ram, R., Trehan, K., \& Jones, T. (2015). Barriers to ethnic minority and women's enterprise: Existing evidence, policy tensions and unsettled questions. International Small Business Journal, 33(1), 49-69. https://doi.org/10.1177/02662426145568 23

Chris, D., Nerys, F. L., Eillen, S., \& Bill, O. G. (2011). Entrepreneurs' perception of business networks: Does gender matter? The International Journal of Entrepreneurship and innovation, 12(4), 
271-281. https://doi.org/10.5367/ijei.2011.0047

Cudmore, B. A., Troshani, A., \& McCoy, J. (2009). Entrepreneurial investment in the Shkodra Region: opportunities for women in tourism. The Entrepreneurial Executive, 14, 31-48.

D‘Exelle, B., \& Holvoet, N. (2011). $=$ Gender and network formation in rural Nicaragua: a village case study. Feminist Economics, 17(2), 31-61. https://doi.org/10.1080/13545701.2011.5 73488

Domenico, M. D. (2008). I'm Not Just a Housewife": Gendered Roles and Identities in the Home-Based Hospitality Enterprise. Gender, Work and Organization, 15(4), 313-334. https://doi.org/10.1111/j.1468-

0432.2007.00388.x

Doyle, W., \& Young, J. D. (2001). Entrepreneurial networks in the micro business sector: examining differences across gender and business stage. Journal of small business and Entrepreneurship, $16(1)$, 17-30. https://doi.org/10.1080/08276331.2001.1 0593297

Duberley, J., \& Carrigan, M. (2012). The career identities of 'mumpreneurs': Women's experiences of combining enterprise and motherhood. International Small Business Journal, 31(6), 629-651. https://doi.org/10.1177/02662426114351 82

Durbin, S. (2011). Creating Knowledge through Networks: a Gender Perspective. Gender, Work and Organization, 18(1), 90-112.

Edralin, D. M. (2013). Work and Life Harmony: An Exploratory Case Study of
Entrepreneurs. DLSU Business \& Economies Review, 22(2), 15-36.

Ekinsmyth, C. (2013). Managing the business of everyday life: the roles of space and place in mumpreneurship. International Journal of Entrepreneurial Behaviour \& Research, 19(5), 525-546. DOI: 10.1108/IJEBR-10-2011-0139

Fiona, W. (2009). An analysis of the role of gender and self-efficacy in developing female entrepreneurial interest and behavior. Journal of Developmental Entrepreneurship, 14(2), 105-119. DOI: 10.1142/S1084946709001247

Foss, L. (2010). Research on entrepreneurial networks: The case for a constructionist feminist theory perspective. International Journal of Gender and Entrepreneurship, 2(1), 83102. DOI:10.1108/17566261011026565

Garcia, M. D., \& Carter, S. (2009). Resource mobilization through business owners' networks: is gender an issue? International Journal of Gender and Entrepreneurship, 1(3), 226-252. DOI:10.1108/17566260910990919

García, M. D., \& Welter, F. (2011). Gender identities and practices: Interpreting women entrepreneurs' narratives. International Small Business Journal, 16(1), 1-21.

Jennings, J. E., \& Brush, C. G. (2013). Research on Women Entrepreneurs: Challenges to (and from) the Broader Entrepreneurship Literature? The Academy of Management Annals, 7(1), 661-713.

https://doi.org/10.5465/19416520.2013.7 82190

John, W., \& Rick, N. (2009). Gender and the SME finance gap. International Journal of Gender and Entrepreneurship, 
l(1), 42-56. DOI: $10.1108 / 17566260910942336$

Kirkwood, J. (2009). Women Entrepreneurs across Racial Lines: Issues of Human Capital, Financial Capital and Network Structures. Women in Management Review, 22(5), 428430.http://dx.doi.org/10.1561/030000002 1

Kirkwood, J. (2012). Family Matters: Exploring the Role of Family in the New Venture Creation Decision. Journal of Small Business and Entrepreneurship, 25(2), 141-154. https://doi.org/10.1080/08276331.2012.1 0593565

Klyver, K. (2011). Gender differences in entrepreneurial networks: adding an alter perspective. Gender in Management, 26(5), 332-350.

Klyver, K., \& Grant, S. (2010). Gender differences in entrepreneurial networking and participation. International Journal of Gender and Entrepreneurship, 2(3), 213227.

Marlow, S., \& Carter, S. (2004). Accounting for change: professional status, gender disadvantage and selfemployment. Women in Management Review, 19, 5-16.

Marlow, S., \& McAdam, M. (2013). Gender and entrepreneurship: Advancing debate and challenging myths; exploring the mystery of the under-performing female entrepreneur. International Journal of Entrepreneurial Behaviour \& Research, 19(1), 114-124. http://dx.doi.org/10.1108/135525513112 99288

Marlow, S., \& McAdam, M. (2013a). Incubation or Induction? Gendered Identity Work in the Context of
Technology Business Incubation. Entrepreneurship Theory and Practice, 1042-2587.

https://doi.org/10.1111/etap.12062

Marlow, S., \& Patton, D. (2009). All credit to men? Entrepreneurship, finance, and gender. Entrepreneurship Theory and Practice, 19, 717-735. https://doi.org/10.1111/j.15406520.2005.00105.x

Marlow, S., \& Swail, J. (2014). Gender, risk and finance: why can't a woman be more like a man. Entrepreneurship and Regional Development, 26((1-2)), 80-96. https://doi.org/10.1080/08985626.2013.8 60484

Marlow, S., Henry, C., \& Cater, S. (2009). Exploring the impact of gender upon women's business ownership. International Small Business Journal, 27(2), $139-148$ https://doi.org/10.1080/08985626.2013.8 60484

Nel, P., Maritz, A., \& Thongprovati, O. (2010). Motherhood and entrepreneurship: the mumpreneur phenomenon. The International Journal of Organizational Innovation, 3(1), 6-36.

Robinson, S. (2007). Business failure rates: a look at sex and location. Academy of Entrepreneurship Journal, 13(1), 2130 .

Roomi, M. A. (2009). Impact of social capital development and use in the growth process of women-owned firms. Impact of social capital development and use in the growth process of women-owned firms, 17(4), 473-495.

Roomi, M. A., Harrison, P., \& BeaumontKerridge, J. (2009). Women-owned small and medium enterprises in England: Analysis of factors influencing the growth 
Process. Journal of Small Business and Enterprise, 16(2), 270-288. DOI: $10.1108 / 14626000910956056$

Sharafizad, J. (2011). Determinants of business networking behaviour of women in small business. Small Enterprise Research, 18(2), 158160.https://doi.org/10.1080/08985626.20 13.860484

Tsuchiya, R. (2010). Neighborhood social networks and female self-employment earnings in Taiwan. International Entrepreneurship Management Journal, 6(2), 143-161. DOI: 10.1007/s11365-0100143-2

Tucker, H. (2009). Women entrepreneurship in Asian developing countries: Their development and main constraints. Journal of development and Agricultural Economics, 1(2), 27-40. DOI: 10.5897/AJBM11.3040
Vadnjal, J., \& Vadnjal, M. (2013). The role of husbands: Support or barrier to women's entrepreneurial start-ups? African Journal of Business Management, 7(36), 3730-373.

Watson, J. (2011). Networking: Gender differences and the association with firm performance. International Small Business Journal, 10(1), 1-23. DOI: 10.5897/AJBM11.3040

Weeks, J. R. (2009). Practitioner section Women business owners in the Middle East and North Africa: A five-country research study. International Journal of Gender and Entrepreneurship, 1(1), 7785. https://doi.org/10.1108/GM-07-20160141

Welter, F. (2004). The environment for female entrepreneurship in Germany. Journal of Small Business and Enterprise 